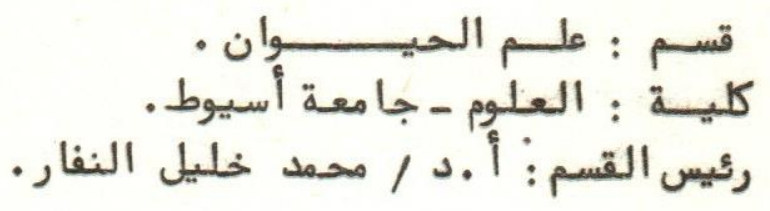

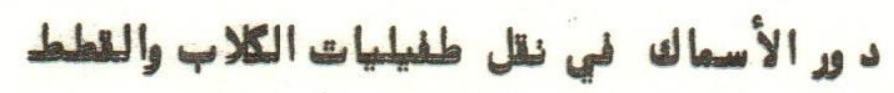

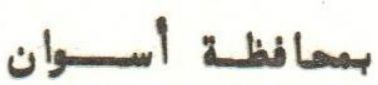

محمد النفار ، محمد مسعود ، اسماعيل حسن

- - تم الحصول على يرقات بعض د يد ان التريماتود ا في تجويف المخ لسمكة

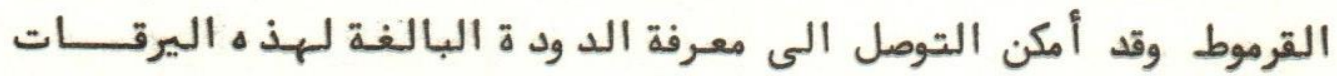

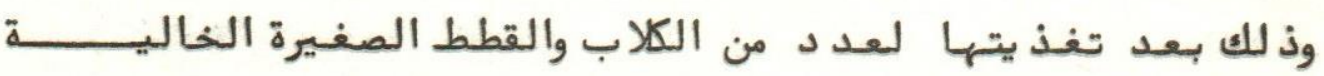

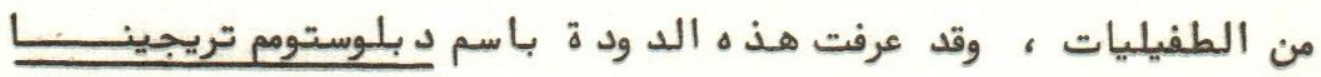

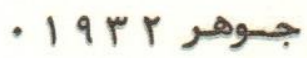

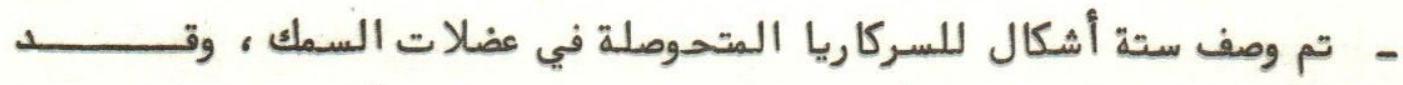

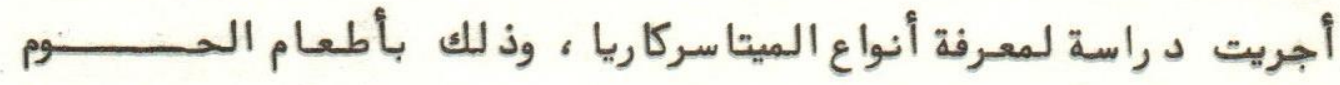

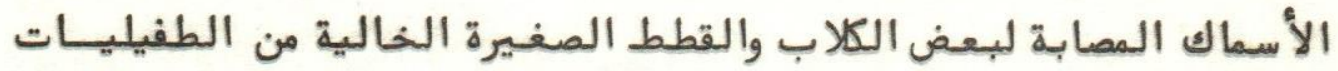

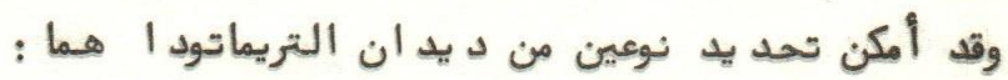

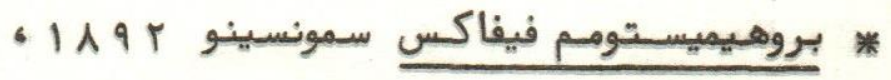
* هابلوركس يوكوجـاوي كاتسـوتا r r ب 9 ا 1 . 
1 


\author{
Dept. of Zoology, \\ Faculty of Science, Assiut University, \\ Head of Dept. Prof. Dr. M.K. EL-Naffar.
}

\title{
ROLE PLAYED BY FISH IN TRANSMITTING SOME TREMATODES OF DOGS AND CATS AT ASSWAN PROVINCE, A.R. EGYPT
}

(With 3 Tables \& 5 Figs.)

\author{
By \\ M.K. EL-NAFFAR; M.F. SAOUD* and I.M. HASSAN \\ (Received at 26/8/1982)
}

\begin{abstract}
SUMMARY
Some trematode larvae were found in the cranial cavity of Clarias lazera and $\mathrm{C}$. anguillaris. Feeding experiments were carried out on parasite-free pupies and kittens. Samples of stool of these animals were examined from the 3rd day after infection to detect any trematode ova. When the ova were detcted, the animals were sacrified to obtain the adult flukes which were identified as Diplostomum tregenna NAZMI GOHAR, 1932.

The examination of fish revealed the presence of 6 forms of metacercariae infesting the muscles of seventeen species of fishes. The metacercariae of each form were fed singly to the parasite-free puppies and kittons. When the ova appeared in stool, the animals were killed to obtain the adult flukes which were identified as prohamistomum vivax SONSINO, 1892 and Haplorchis yokogawi KATSUTA, 1932.
\end{abstract}

\section{INTRODUCTION}

On studying the metacercariae, trematode larvae and the role played by fish in transmitting some trematode of doges and cats, AZIM (1938) reported Haplorchis pumilio LOOSS, 1896; Haplorchis yokogawi KATSUTA, 1932, Haplorchis taichui nishigori, 1924; and prohemistomum vivax SONSINO, 1892 from dogs in Egypt. FAHMY and SELIM (1959) reported some trematode parasites of dogs which are transmitted by fish in Egypt. They found that Mugil cephalus and Tilapia nilotica act as second intermediate hosts for Echinostomum liliputans, Prohemistomum vivax; Heterophyes heterophyes, Heterophyes dispar, Diorchitrema pseudocirratus, Haplorchis spp., plagicola spp., Pygidiospsis genata and stichodora sawakinensis.

FISCHTAL and KUNTZ (1963) studied some metacercariae from Tilapia sp., Tilapia zilli and Clarias sp., collected from Egypt.

KHALIL (1963) described Diplostomulum tregenna, the larval stage of Diplostomum tregenna GOHAR, 1932, from the cranial cavity of Clarias lazera in the Sudan.

FAHMY et al. (1976) studied the encysted metacercariae in some fishes at Assiut province, and after feeding these metacercariae to puppies and Kittens, they succeeded in obtaining two adult parasites: Prohemistomum vivax SONSINO, 1839 and Haplorchis yokogawi KATSUTA, 1932.

* Faculty of Scince, Ain Shams University.

Assiut Vet.Med.]. Vol. 14, No. 27, 1985. 
KHALIFA et al. (1977) studied the heterophyid cercariae and the life cycle of Haplorchis pumilio (LOOSS, 1896) from Assiut Province. They described the cercaria of Haplorchis pumilio from Melania truncatula. They obtained the metaccrcaria of this parasite from the fish Gambosia affinis and Tilapia nilotica. Experimental infestation was successful in white rats and young pigeons.

EL-NAFFAR (1980) studied the life cycle of Haplorchoides cahirinus LOOSS, 1896. He found that Cleopatra bulimoides and Cleopatra cyclostomoides are the first intermediate host for this parasite. Also, he obtained the metacercariae of this parasite from Tilapia and Gambosia, and the adult parasites were collected from the intestine of Bagrus bayad and Chrysichthys auratus.

EL-NAFFAR and KHALIFA (1981) described the metacercaria of a new species Euclenostomum ardeolae, from the kidneys of Tilapia nilotica. They succeeded in obtaining the adult parasite in the buccal cavity of Ardeola ibis ibis.

KHALIFA et al. (in press) desribed two types of metacercariae in the muscles of Clarias lazera, and on feeding these matacercariae to the white rats they obtained the adult flukes which are: Cynodiplostomum azimi and Cynodipiostomum depoisi.

\section{MATERIAL and METHODS}

The fish hosts were caught from different parts of Lake Nasser at Aswan. The hosts examined fall into 17 species belonging to 5 families. The systematic list is proposed according to BOULANGER (1907) as follows: Mormyrus kannume \& $\mathrm{M}$. cashive (Family Mormyidae); Hydrocyon forskalii, $\underline{\mathrm{H}}$. lineatus. $\underline{H}$. brevis, Alestes dentex, $\underline{A}$. nurse and $\underline{A}$. baremose (Family Characidae); Clarias lazera and

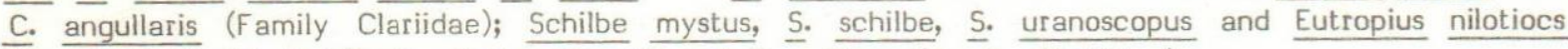

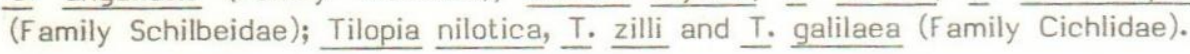

The fishes were examined for trematode larvae and metacercariae. For this purpose, cavities were examined with the help of hand lens, and small pieces of row muscles were examined microscopically. When the fish proved positive, the detected larvae and metacercariae were fed singly to parasite free pupies and kittens. From the 3rd day after feeding, the faeces of these animals was examined daily until the eggs appeared in the stool, then these animals were sacrified and dissected to obtain the adult flukes from their intestines. The trematodes were collected, studied alive, then fixed, stained, and mounted in Canada balsam, and prepared for microscopic examination.

Drawings of the parasites were made to the scale using a camera lucida. The measuraments are given by the scale micrometer. The description and diagnosis was based, at least, on ten specimens except in few cases. All the measuremente are in millimeters.

\section{RESULTS}

1- On the trematode larvae, Diplostomulum tregenna and the adult (experimentally obtained) Diplostomum tregenna NAZMI GOHAR, 1932. During the course of the present work, a developmental stage of trematode larvae (Fig. 1) was found in the cranial cavity of Clarias lazera and Clarias anguillaris. The rate of infection was 3 out of $50(6 \%)$ and one out of $35(2.86 \%)$ respectively. The number of these larvae in C. lazera varied from 7-10 per infected fish, while the number in C. anguillaris was 5 only. 


\section{TREMATODES OF DOGS AND CATS}

The larva is relatively small in size, elliptical in shape with blunty pointed posterior end. It measures $0.600 .68 \mathrm{~mm}$ in length and $0.12-0.17 \mathrm{~mm}$ in width The oral sucker is about $0.035-0.041$ $x \quad 0.023-0.025 \mathrm{~mm}$ and is followed by a small pharynx measures $0.010-0.014 \mathrm{~mm}$ in lenght. The ventral sucker measures $0.023 \mathrm{~mm}$ in diameter and lies nearly in the middle of the body. The holdfast organ measures $0.075-0.032 \times 0.032-0.037 \mathrm{~mm}$ and lies at the begining of the posterior fourth of the body at the mid line.

Family Diplostomidae Poirier, 1886

Subfamily Diplostominae Monticelli, 1892

Genus Diplostomum Nordmann, 1832 Diplostomum tregenna Nazmi Gohar, 1932

The present parasite was recovered from the intestine of puppies and kittens five days after feeding on the Diplostomulum larvae found in the cavity of both Clarias lazera and C. anguillaris from lake Nasser. Ten and four specimens were recovered respectively from the used one dog and one cat.

\section{Description:}

The body (Fig. 2) is 1.51 to $1.76 \mathrm{~mm}$ long. It is distinguished into two regions, the fore-body which is dorso-venterally flattened, slightly concave venterally measuring $0.72-0.81 \mathrm{~mm}$ in length and $0.56-0.75 \mathrm{~mm}$ in maximum width; and the hind-body which is conical, blunty pointed posteriorly, measuring $0.79-0.99 \mathrm{~mm}$ in length and $0.77-0.86 \mathrm{~mm}$ in maximum width The tegument is devoid of spines or scales.

The oral sucker is terminal and in some specimens, it projects a little anteriorly, measuring $0.082-0.11 \mathrm{~mm}$ in diameter. At either side of the oral suker, a cup to ear like process (Pseudosucker), each is $0.08-0.13 \times 0.04-0.06 \mathrm{~mm}$, and together with the oral sucker, they form a trilobed shaped at the anterior end. The ventral sucker is rounded and lies, nearly, in the middle of the fore-body slightly anterior to the holdfast organ and measuring $0.055-0.080 \mathrm{~mm}$ in diameter. The holdfast organ lies just above the junction of the fore-body with the hind-body and is rounded, oval to slightly elongated, measuring $0.143-0.275 \times 0.126-0.302 \mathrm{~mm}$. The oral sucker is directly followed by a muscular pharynx which measures $0.044-0.066 \times 0.049-0.060 \mathrm{~mm}$, and this is followed by a very short oesophagus which bifurcates into two intestinal caeca that terminate in the hind-body, slightly posterior to the posterior testis. The course of these caeca, in its most length could not be traced easily due to the distribution of the vitellaria.

The hind-body contains the reproductive organs. The anterior testis is claviform, measuring $0.27-0.30 \times 0.27-0.33 \mathrm{~mm}$. The posterior testis is bilobed, its right lobe measures $0.38-0.49 \times 0.22-41$ $\mathrm{mm}$ and the left lobe measues $0.35-0.51 \times 0.19-0.33 \mathrm{~mm}$. The ovary is oval in shape, lies opposite to the anterior testis, slightly to the left of the median line and measures $0.11-0.18 \times 0.055-0.16 \mathrm{~mm}$. The vitelline follicles are distributed over the posterior half of the fore-body from the posterior end of the fore-body up to the level of the ventral sucker. The uterine duct unites in its termination by the ejaculatory duct and the formed common short passage ending in the genital atrium which is $0.22-0.30 \mathrm{~mm}$ in diameter and lies on the dorsal side very near to the posterior extremity.

The eggs are few, about $1-3$ in number, oval shaped, thick shelled and yellowish in colour. Each egg is about $0.08-0.012 \times 0.06-0.07 \mathrm{~mm}$.

\section{Discussion:}

KHALIL (1963), while he was working on the cranial nerves of the Nile fish Clarias lazera from the white and the Blue Nile in Khartoum area in the Sudan, found a very large number of 
60

EL-NAFFAR, et al.

trematode larvae. Most of the fish which he examined were found to be heavily infected, each with several hundreds of the parasite. Few of these infected fishes show haemorrhage, suggesting that the parasites reached the brain through the brain through the blood stream. He described and identified the three stages of these larvae as Diplostomulum tregenna.

The occurance of the present larval stage of Diplostomulum tregenna in Clarias anguillaris in Lake Nasser constitutes a new host as well as a new locality for the Diplostomulum tregenna larvae.

The description which was previously given for the adult, leaves no doubt that the parasite under discussion, belongs to the genus Diplostomum NORDMANN, 1832. YAMAGUTI (1958) listed 26 species in this genus.

NAZMI GOHAR (1932 and 1933), described two new species of Diplostomum: the Diplostomum tregenna from the Egyption kite, Milvus migranus aegypticus, and D. azimi from the intestione of an expèrimental dog Canis familiaris in Egypt.

KHALIL (1963) detected Diplostomum tregenna from the intestine intestione of domestic duck, three days after being fed on the Diplostomulum larval stages.

During the present work on Clarias spp., Diplostomum tregenna NAZMI GOHAR, 1932 has been recorded from the intestine of puppies and kittens experimentally fed on the present Diplostomum larval stage.

The obtained results agree to a very extent with Diplostomum tregenna NAZMI GOHAR, 1932 and that described by KHALIL (1963), but there are some differences which can be summerized as follows:

1- NAZMI GOHAR described Diplostomum tregenna from the intestine of Egyptian kite Milvus aegypticus; KHALIL described the parasite under discussion from the intestine of domestic duck, while the present parasite is from the intestine of puppies and kittens fed on the present larval stage of Diplostomum tregenna.

2- The occurrence of the present parasite larvae in Lake Nasser constitutes a new locality.

3- There are sligh differences in the measurements which are given in table (1).

2- On some metacercariae and the adults (experimentally obtained) Prohemistomum vivax (SONSINO, 1892) ASIM, 1933 and Haplorchis yokogawi (KATSUTA, 1932).

The examination of fishes revealed the presence of six forms of metacercariae infesting muscles of the fish.

The first form (Fig. 3a) was found only in Tilapia spp. It measures $0.66-0.74 \mathrm{~mm}$ long by $0.57-$ $0.61 \mathrm{~mm}$ wide. It is oval in shape and surrounded by a thin cyst wall. The larva inside this cyst has an oral sucker measuring $0.13-0.15 \times 0.13-0.16 \mathrm{~mm}$; an acetabulum measuring $0.13-0.14 \times 0.11-$ $0.13 \mathrm{~mm}$, and the excretory vesicle appears as thin capillary tube about $0.311-0.33 \mathrm{~mm}$ in length. The cyst is surrounded at either pole by masses of small fat globules.

The second form (Fig. 3b) occurs also in Tilapia spp. It is nearly spherical in shape, measuring about $0.34-0.40 \mathrm{~mm}$, (average $0.35 \mathrm{~mm}$ ) in diameter. It is surrounded by a thick cyst wall measuring $0.018-0.022 \mathrm{~mm}$. No definite features were observed inside the metacercariae which appeared as blackish mass of vacuoles.

The third form (Fig. 3c) was found also in Tilapia spp. It appeared as a black spot surrounded by a thick cyst wall. The cyst is rounded in shape measuring $0.301-0.345 \mathrm{~mm}$ in diameter, and the cyst wall is about $0.022-0.027 \mathrm{~mm}$, in thickness. The only organ which can be seen, is the oral sucker which measures about $0.038-0.055 \times 0.066-0.073 \mathrm{~mm}$.

Assiut Vet.Med.J. Vol. 14, No. 27, 1985. 


\section{TREMATODES OF DOGS AND CATS}

The fourth form (Fig. 3d) found in Hydrocyon spp., Alestes spp., Schilbe spp. and Eutropius niloticus. This cyst measures $0.329-0.385 \mathrm{~mm}$ in diametrer, and is surrounded by an adipose tissue.

The fifth form (Fig. 3e) was found in the muscles of Tilapia spp., Mormyrus spp. and Clarias spp. It appeared as a dull opaque spot, nearly oval in shape, small in size about $0.36-0.42 \times 0.29-$ $0.34 \mathrm{~mm}$. It is surrounded by a thick cyst wall.

The sixth form (Fig. 3f) occurs only in the muscles of Clarias spp. It is seen as a large dull oval spot measuring $1.31-1.42 \times 0.94-1.08 \mathrm{~mm}$. It is surrounded by a thick cyst wall measuring $0.084-$ $0.091 \mathrm{~mm}$. A large sucker measuring $0.20-0.25 \mathrm{~mm}$. in diameter, and two intestinal caeca were distirguished in the metacecaria.

Family Cyathocotylidae Poche, 1926

Subfamily Prohemistominae Lutz, 1935

Genus Prohemistomum Odhner, 1913

Prohemistomum vivax (Sonsino, 1892) Azim, 1933

The present parasite was recovered from the duodenum, jejunum and ileum of puppies and kittens about 6 days after being fed on the previously described metacercariae (Fig. 3a, b, c \& d) of infected Tilapia spp., Hydrocyon spp., Alestes spp. Schibe spp., and Eutropius niloticus from Lake Nasser. Several hundreds specimens of this parasite were collected from the four puppies and four kittens used in the experiment.

\section{Description:}

The flukes (Fig. 4) are pyriform, convex dorsally and concave ventrally behind the middle half of the body. The body measures $1.14-1.91 \mathrm{~mm}$ long, by $0.52-0.82 \mathrm{~mm}$ wide and the length width ratio is about $2: 1$. The cuticle of the anterior half of the body is provided with minute spines.

The anterior half of the body bears the two suckers and the tribocytic (holdfast) organ. The oral sucker is subterminal but in some specimens it projects slight anteriorly, rounded to oval shaped, slightly wider, than long, measuring $0.03-0.06 \mathrm{~mm}$ long by $0.06-0.09 \mathrm{~mm}$ wide. The acetabulum is rounded, slightly smaller than the oral sucker, measures $0.046-0.077 \mathrm{~mm}$ in diameter, and lies anterior to the tribocytic organ, nearly at the end of the anterior third of the body. The tribocytic organ lies in the median line, at the beginning of the middle third. It is mushroom like structure, poorly developed, measures $0.14-0.16 \mathrm{~mm}$ long by $0.11-0.12 \mathrm{~mm}$ wide. The pharynx is well developed, oval in shape, measuring $0.04-0.07 \mathrm{~mm}$ long by $0.05-0.07 \mathrm{~mm}$ wide. This is followed by the oesophagus which measures $0.03-0.06 \mathrm{~mm}$ in length. The oesophagus leads to two intestinal caeca which ending at a level slightly posterior to the posterior testis.

The reproductive organs are situated in the hindbody. The two large testes are tandem in arrangement with a very narrow intertesticular space. The anterior one overlaps the tribocytic organ, measuring $0.22-0.32 \mathrm{~mm}$ long by $0.19-0.34 \mathrm{~mm}$ wide. The posterior testis is larger than the anterior one and measures $0.26-0.37 \mathrm{~mm}$ long by $0.27-0.42 \mathrm{~mm}$ wide. The cirrus pouch is well developed, saccular shaped and has a lateral position at the posterior end, extending at a level reaching about the length of the posterior testis and measures $0.45-0.63 \mathrm{~mm}$ long by $0.099-0.155 \mathrm{~mm}$ wide. It contains the seminal vesicle and rod-shaped cirrus.

The ovary is small, rounded to oval shaped with smooth outline; and its position may be somewhat variable. It lies at the right or left side of the two testes in the majority of the available specimen, and in few specimens it lies between the two testes within the intertesticular space. The ovary measures $0.11-0.22 \mathrm{~mm}$ long by $0.09-0.22 \mathrm{~mm}$ wide. The vitellaria are well developed, irregularly shaped of closely packed follicles confined to two wide bands at either sides of the posterior half of the body extending to the posterior testis forming a complete circle around the tribocytic organ.

Assiut Vet.Med.J. Vol. 14, No. 27, 1985. 


\section{EL-NAFFAR, et al.}

The eggs within the uterus are few, 3-5 in number (average 4), each is large, oval shaped, yellowish in colour and measuring $0.077-0.099 \mathrm{~mm}$ long, by $0.044-0.066 \mathrm{~mm}$ wide.

An excretory bladder was revealed only in alive worms as a small $\mathrm{Y}$ - shaped sac.

\section{Discussion:}

SONSINO (1892) described a cercaria from the snail Cleopatra bulimoides which he called it cercaria vivax. AZIM (1933) found that cercaria vivax could encyst in the fresh water fishes Gambusia affinis and Tilapia nilotica, and when the infected fishes were fed to cats and dogs, the adult recovered were identified as Prohemistomum spinulosum ODHNER, 1913 which was orginally described from the common Egyptian kite Milvus migrans aegypticus, and the specific name (vivax) replaced (spinulosum) by AZIM (1933).

Prohemistomum vivax was described by SONSINO (1892) from Milvus $\mathrm{m}$. aegypticus in Egypt. ODHNER.(1913), DUBOIS (1936), and AZIM (1938) described the same species from the small intestine of dogs in Cairo and Upper Egypt. Another report of natural infection by this trematode was that found by NASR (1941), in the small intestine of man in Egypt. The parasite was recorded also from the Egyptian Kite M.m. aegypticus by NAGATY et al. (1963). EL-NAFFAR and KHALIFA (1975) repoited the first record with $\underline{P}$. vivax in the small intestine of buff back heron Ardeola ibis ibis in Upper Egypt.

FAHMY and SELIM (1959) could produce the adult trematode after experimental feeding of dogs on infected muscles of Mugil and Tilapia. Also, FAHMY et al. (1976) could produce the same species from the duodenum, jejmnum and ileum of puppies and kittens previoully fed on metacercaria infecting Tilapia nilotica; T. zilli; Mormyrus Kannume; Schilbe mystus; Clarias lazera; Hydrocyon forskalii and Alestes nurse in Upper Egypt. species.

The present material of $\underline{P}$. vivax agrees with the description given by previous authors for

The occurrence of the metacercariae of Prohemistomum vivax in Tilapia galilae; Hydrocyon lineatus, $\mathrm{H}$. brevis; Alestes dentex; A. baremose, Eutropius niloticus; and Schilbe uranoscopus constitutes a new intermediate hosts for this parasite.

The occurrence of the metacercaria of the present parasite in Lake Nasser constitutes a new locality.

Table (2) shows the measurements of the adult trematode obtained by the present investigators, in addition to those given by the previous authors.

Family Heterophyidae Odhner, 1914

Subfamily Haplorchiinae Looss, 1899

Genus Haplorchis Looss, $1899 \quad$ Syn. Monorchotrema Hishigori, 1924 Haplorchis yokogawi Katsuta, 1932

This parasite was collected from the ileum of dogs experimentaly fed on the metacercariae (fifth form) found in Tilapia spp.; Mormyrus spp. and Clarias spp. The flukes were found burried deep in the mucous membrane of the intestine of this experimental animal. About 43 specimens of this paraiste were collected from the used puppy (one).

The sexth form of metacercariae did not developed to an adult parasite. This may indicate that puppies are not the final host of this species, and the final host is probably a fish eating bird. 


\section{TREMATODES OF DOGS AND CATS}

\section{Discription:}

The adult (Fig. 5) is oval or pear in shape and extremely small in size, measuring $0.55-0.655 \mathrm{~mm}$ long by $0.366-0.499 \mathrm{~mm}$ wide, (average $0.63 \times 0.43 \mathrm{~mm}$ ). The body is divided distinctly into a mobile fore-body and a hind-body containing the reproductive organs and has a cuticle covered with minute spines.

The oral sucker measures $0.022-0.044 \times 0.031-0.055 \mathrm{~mm}(0.029 \times 0.040 \mathrm{~mm})$ and the acetabulum is $0.031-0.044 \times 0.027-0.033 \mathrm{~mm}(0.037 \times 0.031 \mathrm{~mm})$. It is not easily detected. The prepharynx is short and the pharynx which measures $0.018-0.038 \times 0.022-0.027 \mathrm{~mm}(0.030 \times 0.024 \mathrm{~mm})$ leads to an oesophagus measuring about $0.011-0.044 \mathrm{~mm}(0.039 \mathrm{~mm})$ in length.

The single testis is spherical in shape and lies near the posterior extremity. It measures 0.209$0.291 \times 0.192-0.306 \mathrm{~mm}(0.265 \times 0.264 \mathrm{~mm})$. The cirrus pouch is not observed except in one specimen. The ovary is small, measuring $0.088-1.26 \times 0.0605-0.0967 \mathrm{~mm}$ and located just anterior to the testis. The utèrus which contains numerous eggs, extends from behind the bifurcation of intestinal caeca to the posterior end. The follicular vitellaria are small, few in number and irregularly distributed at the posterior part of the body in the testicular zone.

The ovum is small, measuring $0.029-0.055 \times 0.011-0.022 \mathrm{~mm}(0.035 \times 0.016 \mathrm{~mm})$. Such ovum is operculated, flask-shaped with a knob at the posterior pole.

\section{Discussion:} are:

YAMAGUTI (1958) listed nine species in genus Haplorchis LOOSS, 1899. These nine species

H. pumilio (LOOSS, 1896); $\underline{H}$. microrchis (KATSUTA, 1932); $\underline{H}$. pleurolophocerca (SONSINO, 1896); H. tiachui (NISHIGORI, 1924); ․․ t taihokui (NISHIGORI, 1924); ㅂ. vanissimus (AFRICA, 1938); H. yokogawi (KATSUTA, 1932); ‥ tagoreai CHATTORJ, 1948) and $\underline{H}$. milvi (GOHAR, 1934).

KATSUTA (1932) was the first who discovered and described $\underline{H}$. yokogawi from dogs, cats and rats in Formosa. AZIM (1938) found this species in dogs from Egypt. PEARSON (1964) redescribed this species from the lower part of the small intestine of cats, water rats and eagles from Australia and Egypt. FAHMY et al. (1976) redescribed the same species from the ileum of dogs fed on the metacercaria found in Tilapia sp. in Assiut province.

The present material agrees to some extent with the parasite described by the above authors with slight differences in measurments (Table 3).

The occurrence of the metacercariae of the present parasite in the fish Mormyrus spp., and Clarias spp., which act as intermediate hosts in Lake Nasser at Asswan constitutes new hosts and new locality.

\section{REFERENCES}

Azim, M.A. (1933): On Prohemistomum vivax (Sonsino, 1892) and its development from cercaria vivax Sonsino, 1892. Ztsohr. Parasitenk., 5 (2), 432-436.

(1938): On the intestinal helminths of dogs in Egypt, J. Egypt. Med. Ass. 21 (3), 1-5. Boulenger, G.A. (1907): Zoology of Egypt. The fishes of the Nile, publ. for the Egyptian Government by Hugh Ress, London. Dubois, G. (1936): Noureaux principles de classification des trematodes du groupe des strigeidae. Rev. Suisse. Zool., 43, 507-517.

(1938): Monographie des Strigeida (trematoda) Mem. Soc. neuchatel. Sci. nat., 6, 1-535.

Assiut Vet.Med.J. Vol. 14, No. 27, 1985. 


\section{EL-NAFFAR, et al.}

El-Naffar, M.K. (1970): Studies on the parasites on Nile fishes in Assiut Province of Egypt. Ph.D. Thesis, Assiut University, Assiut, A.R. Egypt.

El-Naffar, M.K. and Khalifa, R. (1975): Parasitofauna of the Egyptian aquatic birds. I. Trematode parasites of the buff-backed heron (Ardeola ibis ibis) in Assiut Govr. Egypt. J. Egypt. Soc. Parasit., Vol. 4 \& 5, 42-56.

and Khalifa, R. (1981): Euclinostomum ardeolae sp. nov. (Trematoda: Clinostomatidae) with the description of its life cycle. J. Egypt. Soc. Parasit. Vol. 11(1), 175-181.

Fahmy, M.A.; Mandour, A.M. and El-Naffar, M.K. (1976): Successful infection of dogs and cats by Prohemistomum vivax Sonsino, 1893 and Haplorchis yokogawi Katsuta, 1932. J. Egypt Soc. Parasit. Vol. 485, 77-82.

Fahmy, M.A.M. and Selim, M.K. (1959): Studies on some trematode parasites of dogs in Egypt with with special reference to the role played by fish in their transmission. Z.F. parasitenKunide, 19, 3-13.

Fischthal, J.H. and Kuntz, R.E. (1963): Trematode parasites of fishes from Egypt. part V. Annulated record of some previously described forms. J. Parasit. 49 (1), 91-98.

Khalifa, R.; El-Naffar, M.K. and Arafa, M.S. (1977): Studies on Heterophyid cercariae from Assiut province, Egypt. I. Notes on the life cycle of Haplorchis pumilio (Looss, 1896) with a discussion on previously described species. Acta. Parasitologica. Polanica, Vol. XXV, 25-38.

Khalifa, R.; El-Naffar, M.K. and Sakla, A.A. (in press): On the cynodiplostomatid parasites (Diplostomidae: Trematoda) with description of their metacercariae. Assiut Medical Journal.

Khalil, L.F. (1963): On Diplostomulum tregenna, the Diplostomulum stage of Diplostomum tregenna Nazmi Gohar, 1932 with an experimental demonstration of a part of the life cycle. J. Helm. 37 (3), 199-206.

Latif, A.F.A. (1974): Fisheries of Lake Nasser. Asswan Regional planning, Lake Nasser Development Center.

Nagaty, H.F.; Rifaat, M.A. and El-Gindy, M.S. (1963): Medical Parasitology and Entomology. AngloEgyptian Bookshop. Cairo.

Nasr, M. (1941): The occurrence of Prohemistomum vivax infection in man, with redescription of the parasite. Lab. and Med. Prog., 2, 135-149.

Nazmi Gohar, M. (1932): Diplostomum tregenna sp.n., a new Trematode parasite of the Egyptian kite. Ann. Mag. nat. Hist. London, 4, 567-573.

(1933): Diplostomum azimi sp.n., a new Trematode parasite of the dog. Ann. Mag. nat. Hist. 10. (63), V. 11, 302-306.

Odhner, T. (1913): Zum naturlichen system der digenen trematoden. VI. Die Ableitung der Holostomiden und die Homologien ihrer Haftorgane. Zool. Anz. 42, 289-318.

Pearson, T.C. (1964): A review of the subfamily Haplorchinae Looss; 1899 (Trematode: Heterophi dae). Parasit. 54 (4), 601-676.

Sonsino, P. (1892): Studi sui parasiti di acqua dolce nei dintorni di Cairo in Fgitto. Festschrift Zum 70. Geburtstage R. leuckarts, S. 137.

Yamaguti, S. (1958): Systema Helminthum. Vol. I. part 1 and part 2. Digenetic Trematodes of Vertebrates. Interscience publishers, New York, London. 


\section{TREMATODES OF DOGS AND CATS}

\section{LIST OF FIGURES}

Fig. (1): Diplostomulum tregenna, the larvae of Diplostomum tregenna (Nazmi Gohar, 1932).

Fig. (2): Diplostomum tregenna (Nazmi Gohar, 1932). Ventral view of the adult.

Fig. (3): Different forms of metacercariae.
a- First form
b- Second form
c- Third form
d- Fourth form
e- Fifth form
f- Sixth form

Fig- (4): Prohemistomum vivax (Sonsino, 1892) Azim, 1932.

Ventral view of the adult, obtained from puppies and kittens after feeding with fish infected with the first four forms of previously described metacercariae.

Fig. (5): Haplorchis yokogawi (Katsuta, 1932) Chen, 1939.

Ventral view of the adult parasite obtained from puppies fed on the fifth form of metacercariae.

Table (1): Diplostomum tregenna Nazmi Gohar, 1932

\begin{tabular}{|c|c|c|c|c|}
\hline & $\begin{array}{l}\text { D. tregenna } \\
\text { measurments by } \\
\text { the present } \\
\text { authors }\end{array}$ & $\begin{array}{l}\text { D. tregenna } \\
\text { measurments by } \\
\text { Nazmi Gohar, } \\
1932\end{array}$ & $\begin{array}{l}\text { D. tergenna } \\
\text { measurments by } \\
\text { Dubios, } 1938\end{array}$ & $\begin{array}{l}\text { D. tregenna } \\
\text { measurments by } \\
\text { Khalil, } 1963\end{array}$ \\
\hline The body length & $1.51-1.76$ & $1.08-1.12$ & 1.27 & $0.79-0.86$ \\
\hline The fore-body & $\begin{array}{ll}0.72-0.81 x \\
0.56-0.75\end{array}$ & $0.52-0.62$ & $0.78 \times 0.53$ & $\begin{array}{ll}0.53 & -0.55 x \\
0.31 & -0.35\end{array}$ \\
\hline The Hind-body & $\begin{array}{ll}0.79-0.99 x \\
0.77-0.86\end{array}$ & $0.48-0.50$ & $0.51 \times 0.45$ & $\begin{array}{ll}0.27 & -0.32 x \\
0.20 & -0.23\end{array}$ \\
\hline Oral sucker & $0.082-0.11$ & $0.09-0.1$ & $0.072 \times 0.85$ & $0.057-0.061$ \\
\hline Pharynx & $\begin{array}{l}0.044-0.066 \times \\
0.049-0.060\end{array}$ & $\begin{array}{l}0.07-0.09 x \\
0.06-0.07\end{array}$ & $0.07 \times 0.57$ & $\begin{array}{l}0.039-0.050 \times \\
0.029-0.036\end{array}$ \\
\hline Ventral sucker & $0.055 \times 0.080$ & $0.06 \times 0.08$ & $0.072 \times 0.092$ & $0.040-0.050 \times 0.057$ \\
\hline Holdfast organ & $\begin{array}{l}0.143-0.275 \times \\
0.126-0.302\end{array}$ & $0.16-0.24$ & $0.225 \times 0.25$ & $\begin{array}{l}0.11-0.14 \times \\
0.089-0.129\end{array}$ \\
\hline Ovary & $\begin{array}{l}0.11-0.18 \times \\
0.055-0.16\end{array}$ & $\begin{array}{l}0.17-0.2 \times \\
0.06-0.10\end{array}$ & $0.09 \times 0.175$ & $\begin{array}{l}0.064-0.079 x \\
0.046-0.064\end{array}$ \\
\hline
\end{tabular}

Assiut Vet.Med.J. Vol. 14, No. 27, 1985. 


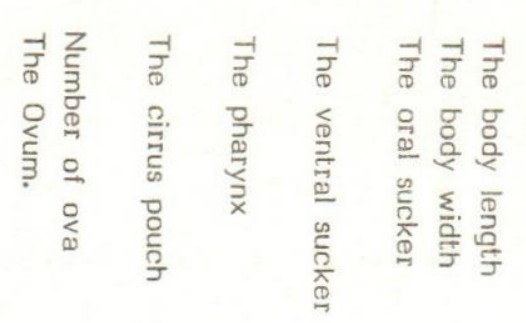

虽虽

o

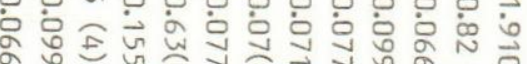

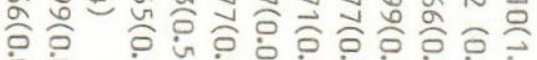

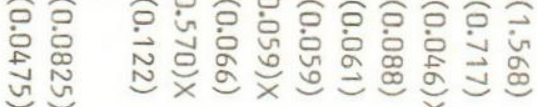

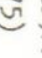

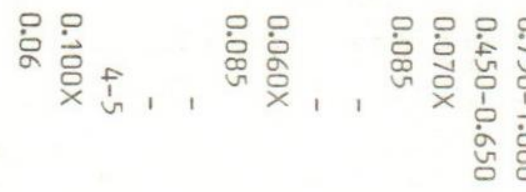

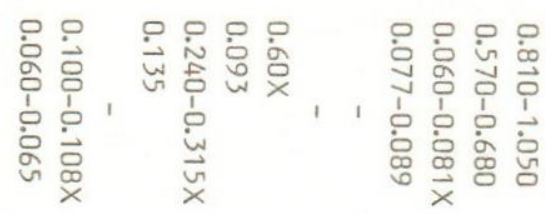

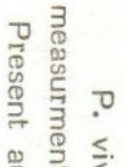

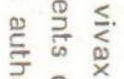

음

宁

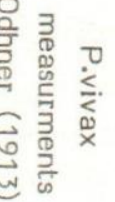

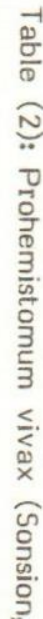

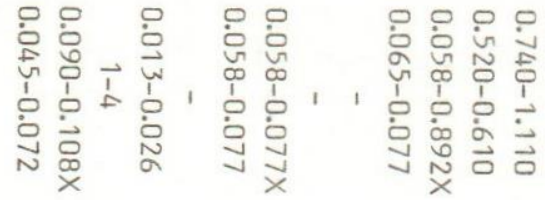

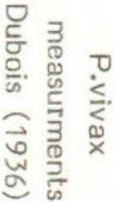

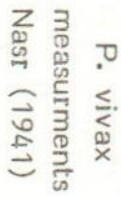

员家

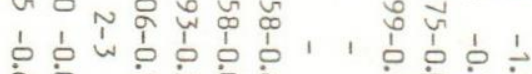

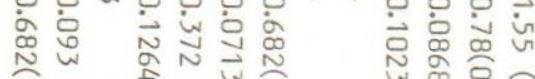

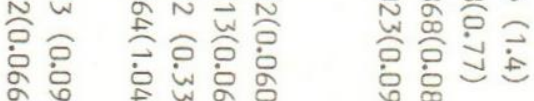

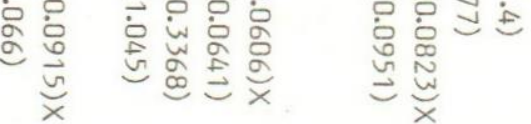

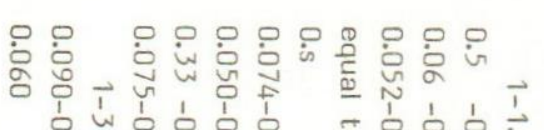

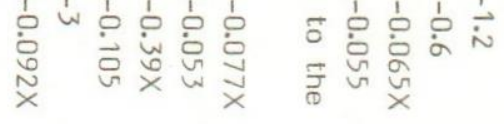

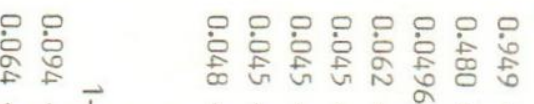

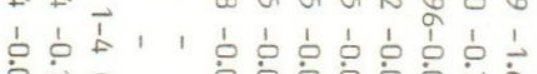

完完

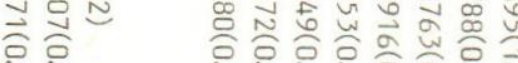

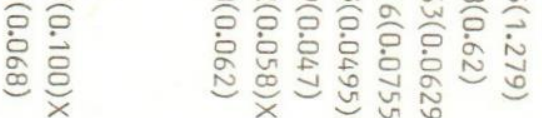

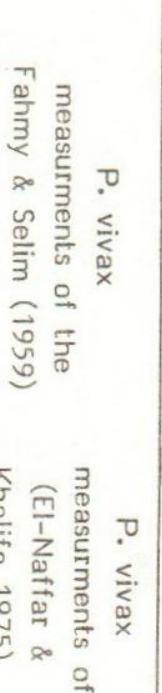

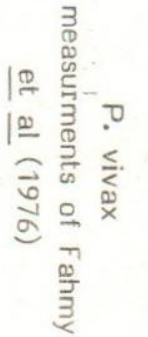




\section{TREMATODES OF DOGS AND CATS}

Table (3): Haplorchis yokogawi (Katsuta, 1932)

\begin{tabular}{|c|c|c|c|}
\hline & $\begin{array}{l}\text { H. yokogawi } \\
\text { measurments by the } \\
\text { present authors }\end{array}$ & $\begin{array}{l}\text { H. yokogawi } \\
\text { measurments by } \\
\text { Pearson (1964) }\end{array}$ & $\begin{array}{l}\text { H. yokogawi } \\
\text { measurments by Fahmy } \\
\text { et al. (1976) }\end{array}$ \\
\hline Body length & $0.555-0.655(0.603)$ & $0.451-0.809(0.349)$ & $0.542-0.722(0.629)$ \\
\hline Body width & $0.366-0.499(0.430)$ & $0.156-0.296(0.218)$ & $0.225-0.271(0.248)$ \\
\hline Oral sucker & $\begin{array}{lll}0.022 & -0.044 & (0.022) x \\
0.031 & -0.055 & (0.040)\end{array}$ & $\begin{array}{l}0.028-0.047(0.042) \times \\
0.040-0.057(0.049)\end{array}$ & $\begin{array}{lll}0.045 & -0.053 & (0.050) x \\
0.045 & -0.064 & (0.053)\end{array}$ \\
\hline $\begin{array}{l}\text { Ventral suc } \\
\text { sucker }\end{array}$ & $\begin{array}{lll}0.031 & -0.044 & (0.037) x \\
0.027 & -0.033 & (0.031)\end{array}$ & $\begin{array}{l}0.017-0.022(0.019) \times \\
0.018-0.026(0.022)\end{array}$ & $\begin{array}{lll}0.017 & -0.020 & (0.018) \\
0.017 & -0.023 & (0.021)\end{array}$ \\
\hline Phyrynx & $\begin{array}{lll}0.018 & -0.038 & (0.030) x \\
0.022 & -0.027 & (0.024)\end{array}$ & $\begin{array}{l}0.025-0.035(0.031) \times \\
0.017-0.024(0.021)\end{array}$ & $\begin{array}{ll}0.026 & -0.032 x \\
0.020 & -0.025\end{array}$ \\
\hline Oesophagus & $0.011-0.044(0.035)$ & $0.021-0.051(0.032)$ & $0.042-0.060$ \\
\hline Testis & $0.209-0.291 \times 0.192-0.306$ & $0.089-0.131(0.108)$ & $0.089-0.119(0.108)$ \\
\hline Ovary & $\begin{array}{l}0.088-0.126(0.098) \times \\
0.0605-0.0967(0.081)\end{array}$ & $\begin{array}{l}0.041-0.066(0.048) x \\
0.047-0.066(0.053)\end{array}$ & $\begin{array}{lll}0.066 & -0.076 & (0.073) x \\
0.061 & -0.076 & (0.067)\end{array}$ \\
\hline Ovum & $\begin{array}{lll}0.029 & -0.055 & (0.035) \times \\
0.011 & -0.022(0.016)\end{array}$ & $\begin{array}{l}0.028-0.030(0.029) \times \\
0.013-0.017(0.015)\end{array}$ & $\begin{array}{l}0.0303-0.0318 \\
0.0153-0.0172\end{array}$ \\
\hline
\end{tabular}

Assiut Vet.Med.J. Vol. 14, No. 27, 1985. 
5

5 


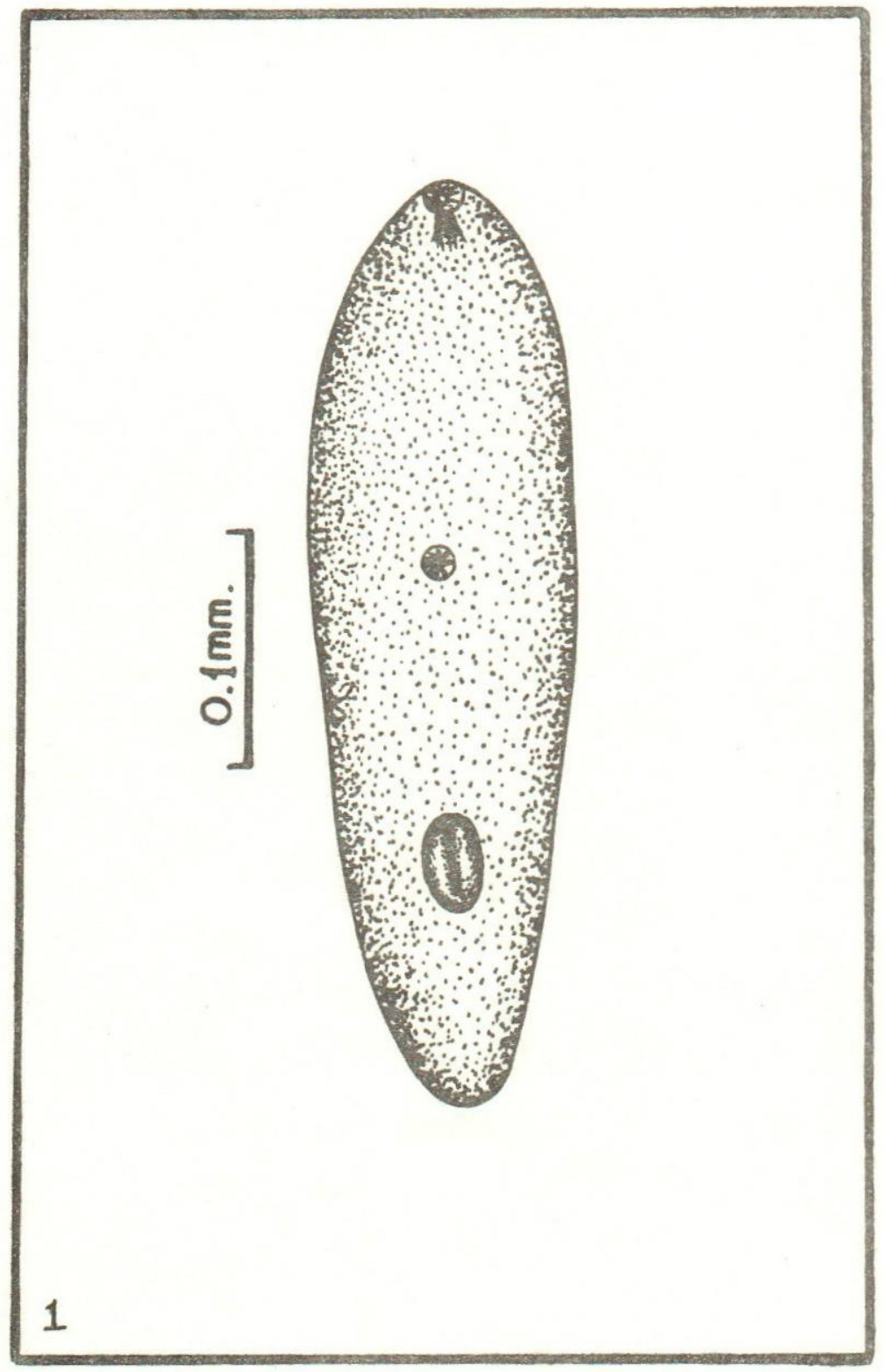




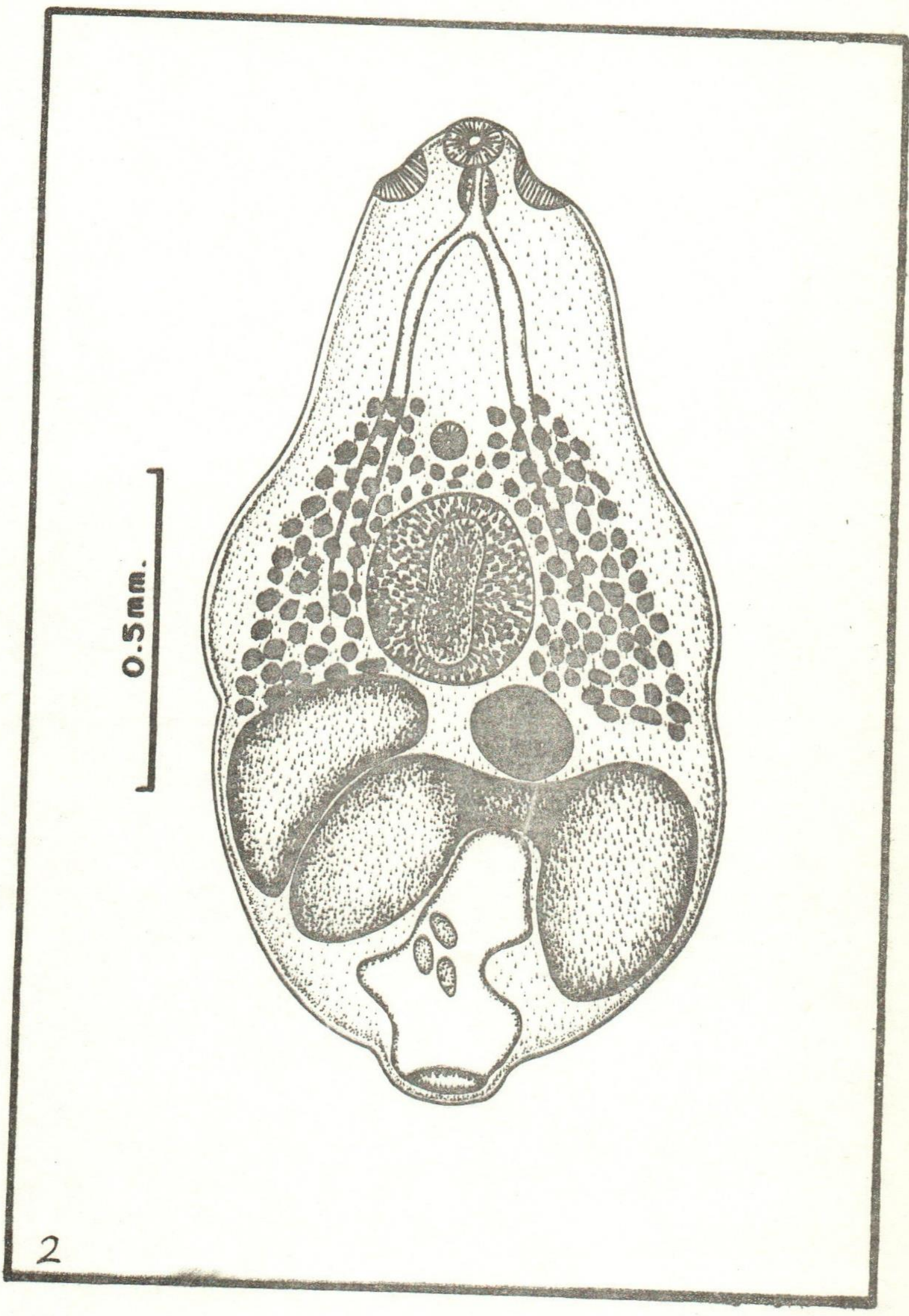


3 


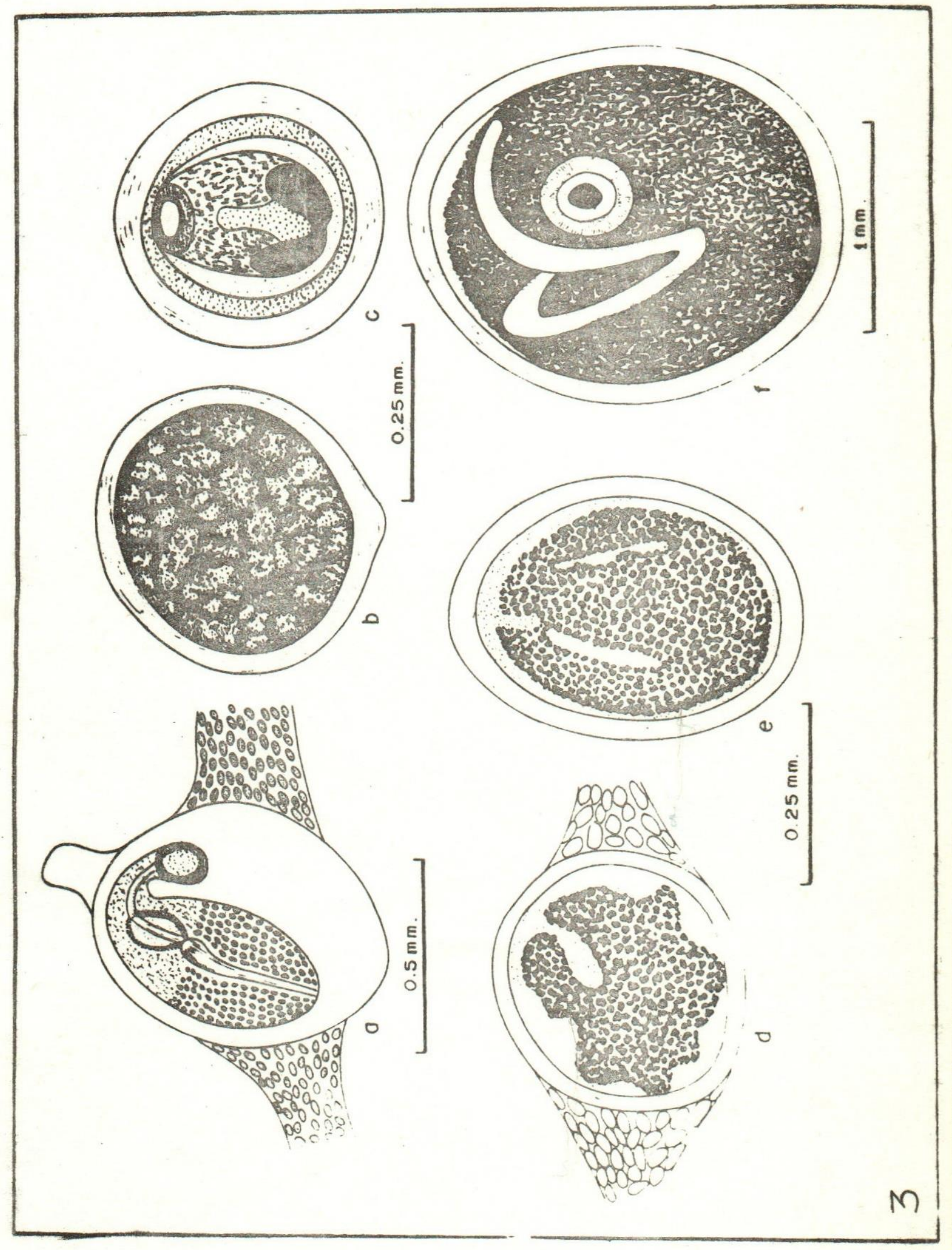


$+1$

3 


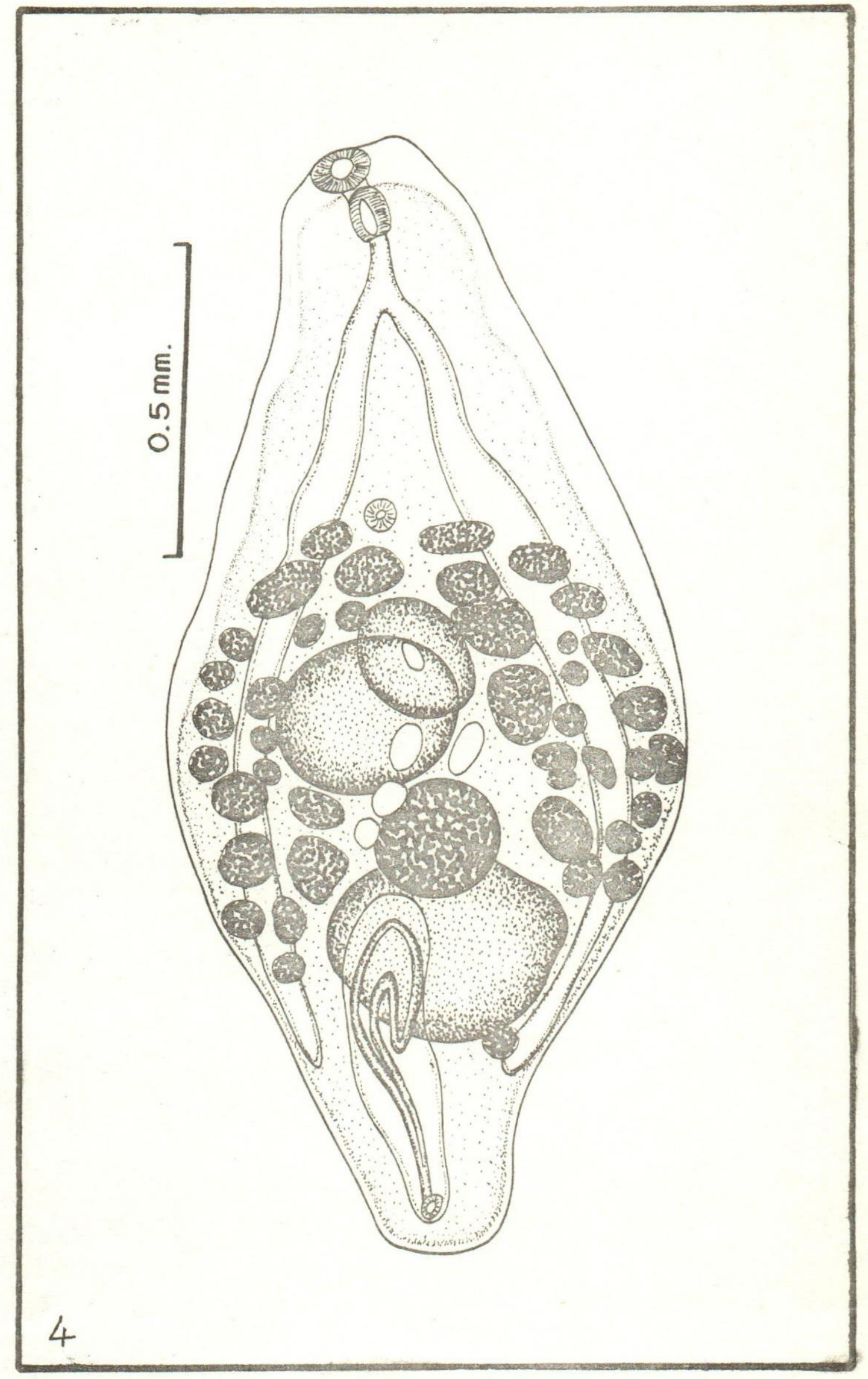




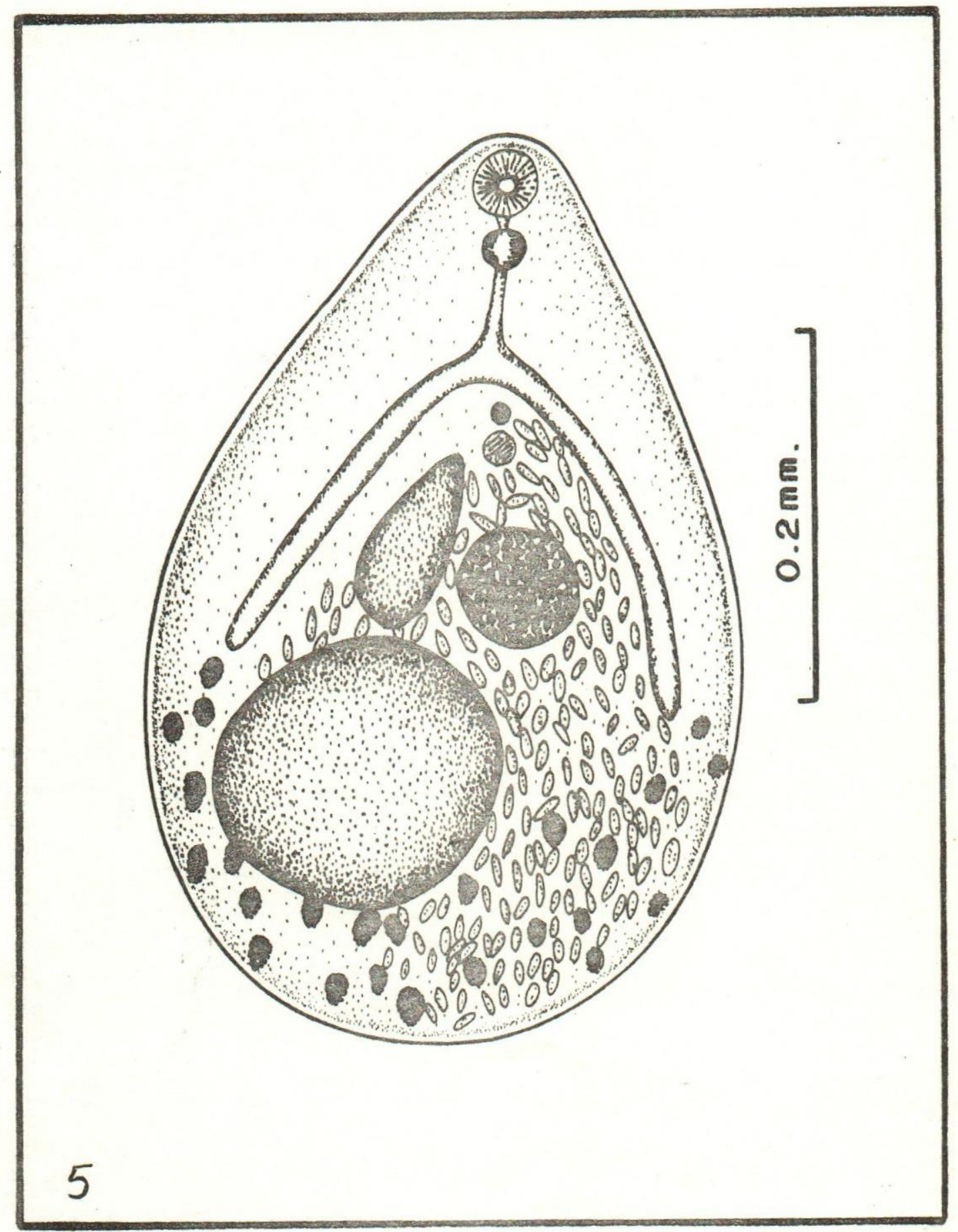


